\title{
Post-colonial State and Bureaucracy in Bangladesh: Theoretical Understanding
}

\author{
Hanif Miah \\ Department of Sociology, Faculty of Social Science, University of Chittagong, \\ Chittagong, Bangladesh \\ E-mail address: miah.hanif@cu.ac.bd
}

\begin{abstract}
Bureaucracy is the management apparatus of a state administration. Even in private sector, bureaucratic organization is very much essential for its smooth functioning and betterment. A legalized domination of bureaucracy only can ensure highest efficiency of an organization in a country. But the state bureaucracy of Bangladesh not developed legally from Pre-colonial period to post-colonial phase as well as an independent Bangladesh eventually. The state bureaucracy of Bangladesh is patrimonial in nature based on personal interests. The politicians and bureaucrats are interdependent in various manners for the fulfillment of their purpose illegally in Democratic Bangladesh. Simultaneously, the impact of militarism still exists in state bureaucracy of Bangladesh as it faced military rule in several times.
\end{abstract}

Keywords: bureaucracy; politicians; Bangladesh; military

\section{INTRODUCTION}

The extension of society is state. Sometimes Plato treats state as society. According to Plato, state grows out of the nature of individual. Plato said, "the state is a natural institution, natural because it reflects the structure of human nature. The origin of the state is a reflection of man's economic needs, for, says Plato, 'a state comes into existence because no individual is self-sufficing; we all have many needs." (Stumpf: 1975). On the basis of knowledge and nature of a society, Plato designed the ideal type of state considering three distinctive classes; King Philosopher, Warrior and Producer. Unlike Plato, Aristotle did not create a blueprint for an ideal state. But in his Politics, Aristotle says that, "it is evident that the State is a creature of nature, and that man is by nature a political animal." (Stumpf: 1975). Aristotle viewed the state as the agency for enabling men to achieve their ultimate goals as human being. Aristotle also sketched the different types of state nature; like Monarchy (one ruler), Aristocracy (few rulers) and Polity (many). He observed three idiosyncratic classes in state; Extreme Rich, Middle class and Extreme poor. His preference was middle class for governing state to the holistic welfare.

As an Enlightenment philosopher, Hobbs, Locke and Rousseau tried to observe state as a new dimension. According to Hobbs state was uneven for the people in primary stage. He argued that social contract to be needed for declining the inequality. According to Locke, the 
uneven nature of state was the golden age of human society which becomes conflicting later. For the resolution of such conflict, absence of common authority is essential, Locke argued. For Rousseau, man is free by birth, but step by step they become chained by social surrounding. In that situation, Rousseau expects the state interference to the freedom of people. From the Marxist point of view, the state is a special organ that appears at a certain moment in the historical evolution of mankind. It is born from the division of society into classes and act as an instrument in the hands of the possessing class for the purpose of maintaining the domination of this class over society. (Mandel: 2003).

This domination causes class conflict in a society. According to Karl Marx, state is the means of economic conflict but noting. Levine stated that the rise of state involved the separation of the public and private spheres and the development of specialized political institutions. (Levine: 1924). Max Weber argued that sometimes political components control over the economic elements in the state on the basis of authority. He characterized three ideal types of legitimate authority by state nature; Rational Legitimacy, Traditional Legitimacy and Charismatic Legitimacy. (Abraham \& Morgan: 1994). According to Weber, modern state based on legal authority which led to formation of governing body called bureaucracy. Without bureaucracy state never run purposively, Weber argued. Our objective of the study is to elucidate state nature according to bureaucratic characteristics on the basis of theoretical understanding in post colonial period of Bangladesh. Weber's explanation of bureaucracy and its later discussion underpins the study for gaining our objectives.

\section{THEORETICAL FRAMEWORK}

\section{The Study of Weber's Bureaucracy}

Historical context of Bureaucracy: Bureaucratic Theory was developed by a German Sociologist and political economist Max Weber. According to him, bureaucracy is the most efficient form of organization which has a well-defined line of authority. It has clear rules and regulations which are strictly followed. Weber believed that a bureaucratic type of organization began in societies whose political organization tended toward officialdom. As described by Ken Morrision, Early examples of societies with large political administrations include the Germanic and Mongolian empires, and feudal estates of the twelfth and thirteenth century. Among these societies, Weber cited the cases of emperors and feudal lords who, when making known their decrees and pronouncements, would appoint commissioners whose power were exercised within the lord's jurisdiction. Weber identified six basic types of Bureaucratic structure: (Morrision: 1998) -

1. States which tend to control policy and policing functions;

2. Ecclesiastical communities which are required to administer to large populations of believers;

3. Economies whose main function is to distribute goods and coordinate functions;

4. The modern agency;

5. The military and

6. The judiciary

Weber looked at the administration of early Egypt and Rome, at the administration of Catholic Church, at Asiatic societies and at feudal economies of central Europe. While these societies develop administrative staff and trained decision maker, they are in weber's view, 
formally pre-bureaucratic in their administration which restricts the development of bureaucracy to modern society. According to Hellen Constas, Weber defined such kinds of bureaucracy is patrimonial bureaucracy depends on charismatic or traditional authority (Constas: 1958).

Mainly Max Weber talked about the bureaucracy based on legal or rational legitimacy in modern industrial society. According to Weber, 'Bureaucracy refers to an instrument that has become indispensible for the rational attainment of the goals of any organization in industrial society'. (Rao: 2000). According to Weber, the term bureaucracy in terms of an organization and management functions refers to the following six principles (Miller: 2008):

Management by rules: A bureaucracy follows a consistent set of rules that control the functions of the organization. Management controls the lower levels of the organization's hierarchy by applying established rules in a consistent and predictable manner.

Division of labor: Authority and responsibility are clearly defined and officially sanctioned. Job descriptions are specified with responsibilities and line of authority. All employees have thus clearly defined rules in a system of authority and subordination.

Formal hierarchical structure: An organization is organized into a hierarchy of authority and follows a clear chain of command. The hierarchical structure effectively delineates the lines of authority and the subordination of the lower levels to the upper levels of the hierarchical structure.

Personnel hired on grounds of technical competence: Appointment to a position within the organization is made on the grounds of technical competence. Work is assigned based on the experience and competence of the individual.

Managers are salaried officials: A manager is a salaried official and does own the administered unit. All elements of a bureaucracy are defined with clearly defined roles and responsibilities and are managed by trained and experienced specialists.

Written documents: All decisions, rules and actions taken by the organization are formulated and recorded in writing. Written documents ensure that there is continuity of the organization's policies and procedures.

Max Weber was the first to give an elaborate account of the development of bureaucracy as well as its causes and consequences. According to Weber, modern officialdom functions in the specific manner. He attributed the following characteristics to bureaucracy in his book 'Economy and Society' (Weber: 1968) -

I. There is the principle of fixed and official jurisdictional areas, which are generally ordered by rules, that is, by laws or administrative regulations.

1. The regular activities required for the purposes of the bureaucratically governed structure are distributed in a fixed way as official duties.

2. The authority to give the commands required for the discharge of these duties is distributed in a stable way and is strictly delimited by rules concerning the coercive means, physical, sacerdotal, or otherwise, which may be placed at the disposal of officials.

3. Methodical provision is made for the regular and continuous fulfillment of these duties and for the execution of the corresponding rights; only persons who have the generally regulated qualifications to serve are employed. 
In public and lawful government these three elements constitute 'bureaucratic authority.' In private economic domination, they constitute bureaucratic 'management.' Bureaucracy, thus understood, is fully developed in political and ecclesiastical communities only in the modern state, and, in the private economy, only in the most advanced institutions of capitalism. Permanent and public office authority, with fixed jurisdiction, is not the historical rule but rather the exception. This is so even in large political structures such as those of the ancient Orient, the Germanic and Mongolian empires of conquest, or of many feudal structures of state. In all these cases, the ruler executes the most important measures through personal trustees, table-companions, or court-servants. Their commissions and authority are not precisely delimited and are temporarily called into being for each case.

II. The principles of office hierarchy and of levels of graded authority mean a firmly ordered system of super- and subordination in which there is a supervision of the lower offices by the higher ones. Such a system offers the governed the possibility of appealing the decision of a lower office to its higher authority, in a definitely regulated manner. With the full development of the bureaucratic type, the office hierarchy is monocratically organized. The principle of hierarchical office authority is found in all bureaucratic structures: in state and ecclesiastical structures as well as in large party organizations and 'private' or private enterprises. It does not matter for the character of bureaucracy whether its authority is called 'public.'

When the principle of jurisdictional 'competency' is fully carried through, hierarchical subordination--at least in public office--does not mean that the 'higher' authority is simply authorized to take over the business of the 'lower.' Indeed, the opposite is the rule. Once established and having fulfilled its task, an office tends to continue in existence and be held by another incumbent.

III. The management of the modern office is based upon written documents ('the files'), which are preserved in their original or draught form. There is, therefore, a staff of subaltern officials and scribes of all sorts. The body of officials actively engaged in a 'public' office, along with the respective apparatus of material implements and the files make up a 'bureau.' In private enterprise, 'the bureau' is often called 'the office.'

In principle, the modern organization of the civil service separates the bureau from the private domicile of the official, and, in general, bureaucracy segregates official activity as something distinct from the sphere of private life. Public monies and equipment are divorced from the private property of the official. This condition is everywhere the product of a long development. Nowadays, it is found in public as well as in private enterprises; in the latter, the principle extends even to the leading entrepreneur. In principle, the executive office is separated from the household, business from private correspondence, and business assets from private fortunes. The more consistently the modern type of business management has been carried through the more are these separations the case. The beginnings of this process are to be found as early as the middle Ages.

IV. Office management, at least all specialized office management-- and such management is distinctly modern--usually presupposes thorough and expert training. This increasingly holds for the modern executive and employee of private enterprises, in the same manner as it holds for the state official.

V. When the office is fully developed, official activity demands the full working capacity of the official, irrespective of the fact that his obligatory time in the bureau may be firmly delimited. In the normal case, this is only the product of a long development, in the public as 
well as in the private office. Formerly, in all cases, the normal state of affairs was reversed: official business was discharged as a secondary activity.

VI. The management of the office follows general rules, which are more or less stable, more or less exhaustive, and which can be learned. Knowledge of these rules represents a special technical learning which the officials possess. It involves jurisprudence, or administrative or business management.

The reduction of modern office management to rules is deeply embedded in its very nature. The theory of modern public administration, for instance, assumes that the authority to order certain matters by decree--which has been legally granted to public authorities--does not entitle the bureau to regulate the matter by commands given for each case, but only to regulate the matter abstractly. This stands in extreme contrast to the regulation of all relationships through individual privileges and bestowals of favor, which is absolutely dominant in patrimonialism, at least in so far as such relationships are not fixed by sacred tradition.

\section{State Bureaucracy in Bangladesh perspective}

Hamza Alavi (1921-2003): There are very few theoretical contribution instituted on the study of post-colonial state like Bangladesh. Alavi's one of the most important works entitled 'The State in post-colonial societies: Pakistan and Bangladesh' based on interpretation of autonomous state in the third world. According to Anupam Sen, 'His main argument is as follows: in the colonial period the bureaucratic military state apparatus was overdeveloped because it had to exercise domination over the native social classes. In the post-colonial period too, Alavi Argues, the state has remain autonomous, because no single class has succeeded in establishing its rule over the over-developed state.' (Sen: 2009). In his theoretical explanation, Alavi tried build up relationship between bureaucracy and other social classes. He also revealed that bureaucracy act as an interwoven among the interest of three social classes; Metropolitan Bourgeoisie, Indigenous Bourgeoisie and Upper class based on land. (Alam: 2007). The main arguments of his theory are as follows -

1. State bureaucracy is overdeveloped in post-colonial societies

2. Indigenous bourgeoisie are underdeveloped

3. State bureaucracy is autonomous.

He also pointed out that the post-colonial state is surrounded and driven by powerful bureaucratic military. This point is very much applicable to understand post-colonial state nature of Bangladesh.

Anupam Sen: He introduced bureaucratic interpretation in his $\mathrm{PhD}$ dissertation from new-Marxist point of view. Dr. Sen tried to find out the limitation of Hamza Alavi's interpretation of Bureaucracy and state nature of post-colonial Bangladesh. According to Sen, 'It is true that, as he (Alavi) asserts, the classes in most third world countries are underdeveloped. But it is not true; as he claims that the state apparatus was over development in the colonial period. In fact, in many independent but semi-colonized countries - such as most Latin American countries and Nepal, Thailand, Afghanistan and Iran for example - the state apparatus, the bureaucracy, the judiciary, etc., remain underdeveloped. (Sen: 2009).

Dr. Sen stated that the social classes in most post-colonial third world societies have failed to establish their hegemony over the state not because the state apparatus was over 
developed by the colonial rulers, as Alavi argues, but because the state was stronger than the social classes long before these societies were colonized.

The state apparatus in most pre-colonial societies was patriarchal but superior vis-à-vis the indigenous social classes. The colonial state apparatus, at least in the case of India 9 (as well as Pakistan and Bangladesh), evolved from the patriarchal Moghul state which the colonizing power inherited.' (Sen: 2009). So, the main features of his theory regarding state of Bangladesh are as follows -

1. State bureaucracy is stronger than the social classes now and long before these societies were colonized that means the state apparatus (Bureaucracy) was overdeveloped before colonial period

2. The state apparatus in most pre-colonial societies was patriarchal and the colonial state apparatus evolved from the patriarchal Moghul state.

3. Historically the state bureaucracy of Bangladesh still bears its pre-colonial and colonial roots.

Emajuddin Ahmed: Another scholar, Dr. Emajuddin Ahmed discussed on Bureaucratic Elites in Bangladesh on his PhD dissertation. Mainly his dissertation based on the study to analyze the nature of the dominant bureaucratic elites in Bangladesh and the development strategy they have been pursuing.

He argues in his study that the ideal relationship between the general public and their leaders, as these civil servants see it, does not differ very much from the colonial pattern. (Ahmed: 1980). He also said the existing administrative structure and the institutional framework were built long ago by the British in colonial India with a view to achieving their limited ends, and these institutions served them well. (Ahmed: 1980). By following the arguments of Dr. Emajuddin Ahmed, the nature of Bureaucracy in Bangladesh would be -

1. The relationships among general public, their leaders and civil servants (Bureaucrats) are colonial in nature.

2. The present Bureaucratic framework is similar as administration in colonial Bangladesh.

A.T.M. Obaidullah: According to him, 'Since Bangladesh does not have, as yet, a composite and unified civil service law as in other countries, the various rules, regulations, manuals, and circulars have the effect of law and government departments as obliged to follow these rules in discharging their day to day administration.

These various statutory and non-statutory rules provide detailed guidelines on recruitment, promotion, and disciplinary action and employee welfare.'(Obaidullah:1999). In the question of promotion, he argues that In respect of promotion and career opportunities discrimination on political consideration happens to be so conspicuous that denies the fundamental rights guaranteed in the constitution.' (Obaidullah: 1999). 'After 21 years of independence the promotion process of 654 officials to the various posts of Bangladesh Secretariat in 1992 overtly manifested the authoritarian attitude and political bias of the government in place of impartiality and objectivity, not tarnished the essence of merit bureaucracy, but also projected disregard for all statutory or non-statutory rules of the civil service, and sanctity of the constitution on the top.

The civil service of Bangladesh as such is in real precarious conditions, amounts to a spoil system, used in the hands of government for effectuating political purposes of the party in power. If the civil servants are considered and treated merely as servants of the government instead of the servants of the state/ republic, security guaranteed to them by law 
may be jeopardized by capricious intervention of government with political motive', he exemplified. (Obaidullah: 1999). In essence, he wanted to illustrate that -

1. Bangladesh has no rational bureaucracy as other countries have in a sense of legal policy, rules and regulation.

2. Absence of impartiality and objectivity in bureaucratic managements.

\section{UNDERSTANDING THE NATURE OF STATE BUREAUCRACY IN BANGLADESH}

The British established their rule in Bengal by defeating Mughol Empire in 1757. As described by Willem Van Schendel, 'On a fine June day in 1757 thousands of men were fighting in a mango orchard close to the border of present-day Bangladesh. This battle became famous as a turning-point in the history of South Asia. It took place in the small village of Polashi, and the encounter established the British East India Company as the new territorial overlord over Bengal. Within a century this trading conglomerate would capture practically all of South Asia.

Historians have often described the Battle of Polashi as the beginning of British colonial rule in South Asia, a rule that would last till 1947'. (Willem: 2009). And Bangladesh became free containing constitutional law; secularism, socialism, democracy and nationalism from Pakistani colony by Liberation War in 1971 after the partition of Indian sub-continent into India and Pakistan in 1947. For handling British rule properly, they established an administrative structure by following Mughol patriarchal bureaucracy which is remaining in the characteristics of post-colonial bureaucracy of Bangladesh.

Before the industrialization in Europe, British were driven by patrimonial bureaucracy as mentioned by Max Weber. They introduced the same bureaucratic structure (as apparatus of Plato's ideal state) in Indian-subcontinent for ensuring proper taxation only.

The authority of tax collection of Zamindar (Landlord) was given by the state, they have no own authority to doing this. They were only the servants of state; state didn't serve them as western Landlord served by their state. That's why, after feudalism, western Bourgeoisie was able to emerged rational bureaucracy during industrialization. But it was not happened in Indian sub-continent.

Even in post-colonial Bangladesh, there is no any dominant class who can materialize the state bureaucracy to establish their well-being. In that sense, the interpretations of state bureaucracy in Bangladesh by Hamza Alavi and Anupam Sen are quite applicable; Indigenous bourgeoisie are underdeveloped and state bureaucracy is autonomous as well as state bureaucracy is stronger than the social classes now and long before these societies were colonized.

Maw Weber identified precise distinguishes between Patrimonial and Rational Bureaucracy by observing Europe and Asian societies. Dr. Aupam Sen specified that differentiation by following ways which can be presented in a table (Sen: 1999) - 


\begin{tabular}{|c|c|}
\hline Patrimonial Bureaucracy & Rational Bureaucracy \\
\hline 1. Bureaucrats were recruited by & 1. Bureaucrats were recruited on the \\
\hline $\begin{array}{l}\text { 2. Durability of profession depended on } \\
\text { personal interest }\end{array}$ & $\begin{array}{l}\text { 2. Recruitment was impersonal and } \\
\text { based on rules and regulation }\end{array}$ \\
\hline 3. There was no written documents & 3. Written documents for accountability \\
\hline $\begin{array}{l}\text { 4. Have no role in the development of } \\
\text { Capitalism }\end{array}$ & $\begin{array}{l}\text { 4. Have significant role in the } \\
\text { development of Capitalism }\end{array}$ \\
\hline
\end{tabular}

After the liberation war, in independent (post-colonial) Bangladesh, has a clear-cut recruitment policy which is established for rationalizing bureaucracy on the basis of legal authority. But what is the real scene exist in nature. It will be clear by understanding state and bureaucratic nature in this country. In Democratic system in Bangladesh, Politicians claim for power is based on popular mandate while that of bureaucrats on merit, competence and political backing. (Anisuzzaman: 2012). One the other hand, politician need to pursue for getting nomination for election to the bureaucrats. According to Zafarullah, 'Bureaucrats can have considerable impact on governance because of their ability to mobilize political support and to apply or deny their administrative skills and technical expertise'. (Zafarullah: 1992).

He also added that it (Bureaucracy) is no longer the neutral instrument of policy implementation in the hands of politicians.' (Zafarullah: 1992). But in western bureaucracy still remains structurally subordinate to politics. (Ahmed: 2009). In that context, the theoretical explanation of Hamza Alavi is right; the state bureaucracy of Bangladesh is autonomous. In the question of rational bureaucracy, P.K. Agrawal stated that any person who enters the bureaucratic organization now wants to know what his authority is as regards his domain of activities. Authority tends to power; power breeds ego; and ego creates favoritism. ...the ego may be different for different persons according to the environment.

Therefore, ego though purely an internal factor gets liked with external factors comprising family and kinship, caste and religion, language and region, social economic strata.... this leads to inaction legalized in many way. (Agrawal: 1995). But in Bangladesh, persons enter into bureaucracy by pursuing others not on the basis on merit always. This is defined the characteristics of nepotism in public administration in Bangladesh.

According to Jacoby, 'He (Weber) considered official administrative activity as separated from the private sphere of life, and as a condition which had developed over a long period of time.' (Jacoby: 1976). But in Bangladesh, official administrations are not free from private sphere of bureaucrat's life. Still it is difficult for Bangladesh to keep out from such kinds of patriarchy nature of Bureaucracy.

\section{The common features of Bangladesh Bureaucracy}

In essence, the nature of Bureaucracy in Bangladesh shaped by irrational domination historically. In independent Bangladesh, Politicization of Bureaucracy as well as corruption in state bureaucracy emerged tremendously. According to Ishtiaq Jamil, 'Bureaucracy in Bangladesh is now caught in the tug-of-war between the major political parties, especially the party and their allies in power. Their transfer and posting to suitable locations and positions, their promotion, and career are now decided on the basis of their political loyalty. The 
process of manipulating the career of bureaucrats has also led to the division among bureaucrats along party lines. He also added that, 'Political connections are now considered vital for promotion, transfer, posting and even recruitment'. (Jamil: 2007). In a recent study on 'State of bureaucracy in Bangladesh and its reform', Shahidujjaman Khan elicited that the bureaucracy in the country badly suffered due to politicization of the administration. He found that promotions and transfers of the civil servants in the past were entirely on political considerations and a large number of officers, having requisite qualifications, were deprived of due promotions, which created a commotion in the civil administration.

He also added that 'Bureaucracy has, indeed, a sweeping dominance in the state administration of Bangladesh. The neutrality of the bureaucracy is critically threatened because of undue influence by the political leaders. Such situation contributes to the unfairness and poor distribution of public service, which tends to boost the practices of corruption, collusion and nepotism.' (Khan: 2012). He finds out three kinds of problems with Bangladesh's bureaucracy -

First, as per Transparency International (TI) reports, Bangladesh is among the most corrupt countries in the world. The performance of the bureaucracy in Bangladesh is ranked the world's worst, along with those of India and Vietnam.

Second, there are problems with the overlapping structure of bureaucracy, vague divisions between government functions and citizen obligations, and unclear political process of policy formulation.

Third, there are problems with human resources quality.

Khan clearly mentioned that 'Bangladesh inherited the system of bureaucracy from the British that ruled Indian subcontinent for over 200 years. The UK government has reformed the bureaucracy by completely transforming its civil service, making it more accountable to ordinary citizens. Some other countries went for drastic reform of their civil administration. Since independence, Bangladesh has had at least 18 proposals for reform in the bureaucracy. Unfortunately, none of these proposals was materialized.' (Khan: 2012)

By considering the theoretical explanation of Bureaucracy and above discussion, we can summarize the features of state bureaucracy in Bangladesh in the given ways-

\begin{tabular}{|c|c|c|}
\hline $\begin{array}{l}\text { Measures of } \\
\text { distinctiveness of } \\
\text { Bureaucracy }\end{array}$ & Legal Rational Bureaucracy & Bureaucracy in Bangladesh \\
\hline $\begin{array}{l}\text { Legal Framework } \\
\text { (Management by } \\
\text { rules): }\end{array}$ & $\begin{array}{l}\text { A bureaucracy follows a consistent } \\
\text { set of rules that control the } \\
\text { functions of the organization. } \\
\text { Management controls the lower } \\
\text { levels of the organization's } \\
\text { hierarchy by applying established } \\
\text { rules in a consistent and } \\
\text { predictable manner. }\end{array}$ & $\begin{array}{l}\text { Bangladesh has no composite } \\
\text { and unified rule of } \\
\text { management in Bureaucracy } \\
\text { yet. Bureaucracy controlled } \\
\text { by political parties, especially } \\
\text { the party and their allies in } \\
\text { power. }\end{array}$ \\
\hline
\end{tabular}




\begin{tabular}{|c|c|c|}
\hline $\begin{array}{l}\text { Written Rules and } \\
\text { regulation (Division of } \\
\text { Labor): }\end{array}$ & $\begin{array}{l}\text { Fixed division of labor among } \\
\text { bureaucrats; who is doing what } \\
\text { needs to be clearly spelled out in } \\
\text { rules. }\end{array}$ & $\begin{array}{l}\text { As above and overlapping } \\
\text { responsibilities; mixed up of } \\
\text { private and official sphere of } \\
\text { life. }\end{array}$ \\
\hline $\begin{array}{l}\text { Principles of Hierarchy } \\
\text { (Formal hierarchical } \\
\text { structure): }\end{array}$ & $\begin{array}{l}\text { An organization is organized into a } \\
\text { hierarchy of authority and follows } \\
\text { a clear chain of command. }\end{array}$ & $\begin{array}{l}\text { Politicization of bureaucracy } \\
\text { creates illegal relation among } \\
\text { officials and breakdown the } \\
\text { chain of commands. }\end{array}$ \\
\hline $\begin{array}{l}\text { Principles of } \\
\text { Appointments } \\
\text { (Personnel hired on } \\
\text { grounds of technical } \\
\text { competence): }\end{array}$ & $\begin{array}{l}\text { Recruitments of bureaucrats must } \\
\text { take place on the basis of required } \\
\text { qualification and work is assigned } \\
\text { based on the experience and } \\
\text { competence of the individual. }\end{array}$ & $\begin{array}{l}\text { Appointment, the } \\
\text { specification of task and } \\
\text { place depends on personal } \\
\text { interests and political } \\
\text { relations. }\end{array}$ \\
\hline $\begin{array}{l}\text { Professional (Managers } \\
\text { are salaried officials): }\end{array}$ & $\begin{array}{l}\text { A manager is a salaried official } \\
\text { and does own the administered } \\
\text { unit. All elements of a bureaucracy } \\
\text { are defined with clearly defined } \\
\text { roles and responsibilities and are } \\
\text { managed by trained and } \\
\text { experienced specialists. }\end{array}$ & $\begin{array}{l}\text { Lack of skilled officials, } \\
\text { Presence of corruption and } \\
\text { nepotism. }\end{array}$ \\
\hline $\begin{array}{l}\text { Documentation } \\
\text { (Written documents): }\end{array}$ & $\begin{array}{l}\text { All decisions, rules and actions } \\
\text { taken by the organization are } \\
\text { formulated and recorded in } \\
\text { writing. Performance to be } \\
\text { governed on the basis of formal, } \\
\text { universal, uniform, and stable } \\
\text { rules. }\end{array}$ & $\begin{array}{l}\text { Weak documentation process } \\
\text { due to lack of accountability } \\
\text { and corruption. }\end{array}$ \\
\hline
\end{tabular}

\section{CONCLUSION}

The state bureaucracy of Bangladesh is patriarchal in nature. But, there are some outward characteristics manifested in its framework which is the expression of rationalizing bureaucracy. In particular, documentation, accountability, recruitment policy, hierarchy and division of labors of state bureaucracy of Bangladesh are legalized visibly. The skill of bureaucrats in this state is questionable, where skilled managerial body was the precondition of Weber's ideal type of bureaucracy on the basis of legal authority.

On the other hand, the theoretical explanations of Hamza Alavi and Anupam Sen are more applicable to understand the state nature and bureaucratic characteristics of Bangladesh. Eventually, before and after independence, Bangladesh faced military rule in several times. It caused the military influence in its bureaucratic organization. 


\section{References}

[1] Tumpf, S.E. 1975. Socrates to Sartre: A History of Philosophy $2^{\text {nd }}$ ed. McGraw-Hill Book Company. United States of America

[2] Mandel, E. 2003. Origin and Development of the State in the History of Societies: The Marxist Theory of the State. Retrieved on March 05, 2013 from http://internationalviewpoint.org/spip.php?article187

[3] Levine, A. 1924. Sociology: an Introduction. Random House. New York.

[4] Abraham, F. \& Morgan, J.H.1994. Sociological Thought from Comte to Sorokin. Macmillan India Limited.

[5] Morrision, K. 1998. Formation of Modern Social Thought. SAGE Publication. London.

[6] Constas, H. 1958. Max Weber's Two Conceptions of Bureaucracy. American Journal of Sociology. Vol. 63, No. 4.

[7] Rao, C.N.S. 2000. Sociology: Primary Principles of Sociology with an Introduction to Social Thought. S. Chand \& Company Ltd. New Delhi.

[8] Weber, M. 1968. Economy and Society. G. Roth, C. Wittich, Eds. \& Trans. New York. Retrieved on March 5, 2013:

http://www.faculty.rsu.edu/users/f/felwell/www/TheoryWeb/readings/WeberBurform.ht $\mathrm{ml}$

[9] Miller, K. 2008. Organizational Communication: Approaches and Processes. Wadsworth Publishing. United States. Retrieved on March 6, 2013: http://suite101.com/article/maxweber-bureaucracy-theory-a267433

[10]Alam, K. 2007. Classical and contemporary Sociological Theory. Kabir Publication. Dhaka.

[11] Sen, A. 2009. The state, industrialization and class formations in India: A neo-Marxist perspective on colonialism, underdeveloped and developed. Routledge \& Kegan Paul. London.

[12] Ahmed, E. 1980. Bureaucratic Elites in segmented economic growth: Pakistan and Bangladesh. University Press Limited. Dacca. Bangladesh.

[13] Obaidullah, A.T.M. 1999. Bangladesh Public Administration: A Study of Major Reforms, Constraints and Strategies. Academic Press \& Publishers Limited. Dhaka

[14] Jamil, I. 2007. Administrative culture in Bangladesh. A H Development Publishing House. Dhaka 
[15] Khan, S. 2012. State of bureaucracy in Bangladesh and its reform. The Financial Express. Dhaka. Retrieved on $24^{\text {th }}$ March 2013 from: http://www.thefinancialexpressbd.com/index.php?ref=MjBfMTFfMDRfMTJfMV82XzE0ODg0NA==

[16] Willem, V. S. 2009. A History of Bangladesh. Cambridge University Press. India.

[17] Sen, A. 1999. Bangladesh: State and Society. Abasar. Dhaka.

[18] Anisuzzaman, M. 2012. Democracy in Bangladesh: Bureaucracy-Democracy's RearGurd - Edited by Mahafuzul H Chowdhury. A H Development Publishing House. Dhaka.

[19]Zafarullah, H. 1992. Understanding Bureaucracy A Primer. Academic Publishers. Dhaka.

[20] Ahmed, N. 2009. Bureaucracy and Local Politics in Bangladesh: A Study in Roles and Relationships. A H Development Publishing House. Dhaka.

[21] Agrawal, P.K. 1995. Motivation and Indian Bureaucracy. M D Publications PVT LTD. New Delhi.

[22] Jacoby, H. 1976. The Bureaucratization of the world (Translated by Eveline Kanes). University of California Press. London 